\title{
Judge Gender, Critical Mass, and Decision Making in the Appellate Courts of Canada
}

\author{
Donald R. Songer \\ Department of Political Science \\ University of South Carolina \\ Columbia, SC 29208 \\ Email: dsonger@sc.edu \\ Phone: 803-777-6801 \\ Susan W. Johnson \\ Department of Political Science \\ University of North Carolina, Greensboro \\ Greensboro, NC 27402 \\ Phone: 336-256-0512 \\ Email: swjohnso@uncg.edu \\ Nadia A. Jilani \\ Department of Political Science \\ University of South Carolina \\ Columbia, SC 20208 \\ Email: jilani@mailbox.sc.edu \\ Phone: 803-777-7378
}

\begin{abstract}
According to Justice Bertha Wilson, there is "overwhelming evidence that gender-based stereotypes are deeply embedded in the attitudes of many male judges" and that "gender difference has been a significant factor in judicial decision-making”. Unfortunately, Justice Wilson's observation has been subjected to few empirical tests. At the same time, scholarship suggests that in other contexts (e.g., legislatures), the presence of a "critical mass" of women may be necessary before substantive gender based differences emerge. It is important to know whether these gender differences do exist and whether they only appear after a "critical mass" of women have been appointed because an implicit premise in the argument for affirmative diversification in elite appointments is that gender matters substantively. We seek to explore the validity of these assumptions by analyzing the votes of judges in the Supreme Court and the provincial appellate courts of Canada. Canada provides an ideal setting to explore these questions because since the early 1980s female representation on appellate courts has gone from virtually non-existent to $44 \%$ on the Supreme Court and over $50 \%$ on some appellate courts. We propose to test whether there are gendered patterns of voting, and if so, whether such patterns appear only after a critical mass is reached, using a logistic regression model of the differences in the voting behavior of male versus female justices, using the universe of Supreme Court votes from 1982 through 2007 and a sample of the votes of judges on the provincial courts of appeal. Our analysis then comes to the conclusion that supports previous research into gendered voting; namely that women vote more liberally on civil rights and equality as well as private economic cases, and more conservatively on criminal cases. However, we find no evidence that indicates a need for women judges and justices to be accompanied by other female colleagues for them to vote sincerely.
\end{abstract}





\section{Introduction $^{1}$}

The first female U.S. Supreme Court justice, Sandra Day O’Connor, once remarked that "there's simply no empirical evidence that gender differences lead to discernable differences in rendering judgment” (Woodruff 2003). On the other hand, Bertha Wilson, the first female appointed to the Supreme Court of Canada, remarked that there is "overwhelming evidence that gender-based myths, biases, and stereotypes are deeply embedded in the attitudes of many male judges" and that "gender difference has been a significant factor in judicial decision-making, particularly in the areas of tort law, criminal law, and family law” (Wilson 1990, 512). Justice Wilson's view illustrates the "different voice" theory of female decision-making, the theory that women view the world differently from men, and that female judges often bring this alternative perspective to bear on the cases they decide (Wilson 1990). She argues that the addition of more women to the bench could make a difference in the law, if "women judges, through their differing perspectives on life, can bring new humanity to bear on the decision-making process” (Wilson 1990, 522). Former Canadian Supreme Court Justice L'Heureux-Dube agrees and points to her own opinions as evidence. In $R v$. Seaboyer ${ }^{2}$ she argued in dissent that the "rape-shield" law under consideration was the product of decades of myths and stereotypical thinking about sexual assault. Similarly, in Symes $v$. Canada, ${ }^{3}$ she disagreed with her male colleagues about what constituted a valid business expense in income tax law. She argued that the provisions were based on the experiences of male businessmen and neglected to consider the experiences of professional females (L'Heureux-Dube 1997).

Debate about whether there are any basic differences in the approaches to decision making between male and female judges is further complicated by disagreement over the extent to which differences in the judicial context may facilitate or constrain the expression of such differences. In particular, some scholars have suggested that gender differences are unlikely to be expressed when there are only "token" numbers of women on a given court; instead the argument is sometimes made that a "critical mass" of

\footnotetext{
${ }^{11}$ The authors gratefully acknowledge the support of the National Science Foundation of the US and the Canadian Embassy to the United States for their support that made this research possible. The interpretations of the data and the conclusions are of course the authors and are not endorsed by either the National Science Foundation or the Canadian Embassy. Grant support for the coding to 1946 was provided by the Canadian Embassy's Canadian Studies Research Grant Program. Three grants contributed to this project, 1) "An Institutional Perspective to Supreme Court Decision Making in Canada and the United States," Susan W. Johnson, principal investigator; 2) "An Empirical Analysis of Decision making in the Supreme Court and Courts of Appeals; of Canada and the United States,” Donald R. Songer, principal investigator; and 3) "Reconceptualizing the Role of Precedent in the Supreme Court of Canada"," Donald R. Songer, principal investigator. Much of the statistical analysis in this book was based on The High Courts Judicial Database (HCJD). The HCJD is a public access database created by Stacia L. Haynie, Reginald S. Sheehan, Donald R. Songer, and C. Neal Tate with the support of grants provided by the Law and Social Science Program of the National Science Foundation (NSF). These data were collected under two grants funded by the National Science Foundation, "Collaborative Research: Fitting More Pieces into the Puzzle of Judicial Behavior: a Multi-Country Database and Program of Research,” SES-9975323; and "Collaborative Research: Extending a Multi-Country Database and Program of Research,” SES-0137349, C. Neal Tate, Donald R. Songer, Stacia Haynie and Reginald S. Sheehan, Principal Investigators. It is available for public use and download at http://sitemason.vanderbilt.edu/site/d5YnT2/data_sets.

${ }^{2}$ (1991) 2 S.C.R. 577.

3 (1993) 4 S.C.R. 695.
} 
women must be reached before gender differences have significant effects. (Allen and Wall 1993, Manning and Carp 2005, Peresie 2005, McCall 2002)

In the remainder of this paper, we build on existing studies of the effect of judge gender on decision making in appellate courts. While it is clear that the gender of judges may matter for a number of reasons, both substantive and symbolic, we focus on the potential substantive effects of judge gender on decision making. The analysis proceeds in two stages. First we attempt to replicate existing studies suggesting that there are significant differences between the voting patterns of male and female judges. We then extend the analysis to explore the extent to which gender specific voting patterns depend on the number of colleagues of the same gender a judge sits with on their court. We explore these potential gender differences by analyzing the votes of judges in the top appellate courts in Canada. These appellate courts provide an ideal setting in which to test for the effects of a critical mass on gendered voting because the gender diversification of the courts has proceeded rapidly over the past 30 years, going from virtually no female representation in any appellate court before the adoption of the Charter of Rights to the current diverse environment in which women constitute over $40 \%$ of the justices on the Supreme Court and the courts of appeal in Alberta and British Columbia.

\section{The Increasing Gender Diversification of Canadian Courts}

Beginning with the appointment of Justice Wilson in 1982, a total of seven women have served on the Supreme Court of Canada (see Figure 1). Currently, four of the nine justices (44\%), including the chief justice, are women. At the appellate level immediately below the Supreme Court, women served on nine of the eleven provincial courts of appeals by 1997. On six of those courts, women comprised at least a fifth of the membership by the turn of the century and on the Court of Appeal of Alberta, fifty percent of the seats were held by women (Greene, et. al. 1998, 25). Currently, women constitute $47 \%$ of the judges on the court of appeal in Alberta, $45 \%$ of the judges in British Columbia, 33\% in Ontario, 30\% of the judges in Quebec, and 22\% of those in New Brunswick.

\section{Theoretical Explanations of Gender Differences}

With the recent additions of female jurists to Canadian and other common law courts, researchers have identified several theories regarding their likely impact on the bench. The scholarship on the impact of gender in U.S. courts has generally produced mixed results. Studies of role theory have attempted to determine whether female judges act as representatives of their respective groups in their decisions (Allen and Wall 1993; Martin 1993a; Segal 2000a), whether they act as tokens by making a conscious effort to vote in agreement with their male counterparts (Allen and Wall 1993), whether they act as outsiders who are more liberal in decisions across all issue areas (Abrahamson 1993), or whether they behave in such a way that can be construed as a "different voice" role (Aliotta 1995; Davis 1993; Martin 1993b; Sherry 1986; Segal 2000b, Ostberg and Wetstein 2004)

In comparing gender behavior on Canadian appellate courts, we take a slightly different approach. Rather than assessing each role theory separately, we look the substantive differences female justices may make in deciding case outcomes, but we also assess whether a "critical mass" of females is necessary in order to see substantive policy differences. 


\section{Previous Empirical Analyses of Gender Differences}

Scholars who have studied the effects of diversification of appellate courts have arrived at mixed results. In the U.S. Supreme Court analyses of O'Connor's voting behavior failed to provide much support for the position that her decision making is distinct strictly because of her gender (Davis 1993; O'Connor and Segal 1990). Davis (1993) and Aliotta (1995), however, found that O’Connor was more supportive of claims involving equality than she was of claims brought against criminal defendants. Palmer (1991), in contrast, concludes that O'Connor's opinion writing provides only mixed support for women's rights and feminism. Preliminary research on U.S. Supreme Court Justice Ruth Bader Ginsburg suggests that the voting behavior of the two female U.S. Supreme Court justices is better explained by their political party affiliation than by their gender (Songer and Clark 2002). However, one recent analysis finds that both of these women are among the Court's strongest supporters of sex discrimination claimants, even though they differ markedly in other areas (Palmer 2002). One should be cautious when drawing conclusions from these small-n studies of O'Connor and Ginsberg exclusively, however these studies do provide the only assessment to date of gender effects in the U.S. Supreme Court.

Studies of gender disparities in other appellate courts conducted on a larger scale have been limited primarily to judicial behavior in the U.S. and generally produced mixed results. Some studies provide evidence to suggest that the effects of gender will vary across issues, and specifically that female judges are more likely to support women's rights claimants (Allen and Wall 1987; Cook 1981; Gryski, Main and Dixon 1986; Kuersten and Manning 2000; Martin 1993; Palmer 1991; 2002). One study of the U.S. appeals courts found significant differences between male and female judges in cases involving employment discrimination, but found no evidence of a gender effect in obscenity and search and seizure cases (Songer, Davis, and Haire 1994).

In their analysis of criminal justice and civil liberties issues on state supreme courts, Songer and Crews-Meyer (2000) found that women judges often took a more liberal position than did their male counterparts, and that their very presence increased the likelihood that male judges would also move toward the left. However, gender had hardly any relevance for the voting behavior of Republican judges. Gender differences were apparent only in the voting behavior of Democratic judges. Therefore, party ideology as well as party selection could be a factor in the disparities among female Republican and female Democrat judges (Songer, Crews-Meyer 2000).

The differences found in previous studies between male and female behavior tend to be limited to appellate courts (see Johnson et. al 2008 and Manning and Carp 2005 for an exception to this).- One analysis of female decision making on the U.S. District Courts found that female judges tend to be less supportive of personal liberties and positions advanced by minority groups than their male colleagues (Walker and Barrow 1985). A study of Clinton district judges similarly concluded that Clinton's female appointees are "no more likely to serve the policy interests of their own communities than are his ... male appointees.” (Segal 2000) A study also found no difference between male and female judges in their consideration of criminal and women's rights cases (Walker and Barrow 1985). A more recent study of the U.S. district courts, however, found gender differences to exist across a wide range of cases, but only within same party comparisons of males and females (Johnson et. al. 2008). 
In addition to the mixed findings from studies of gender on courts in the United States, two studies of gender in Canadian courts have also come to different conclusions. White's (2002) examination of Charter opinions of women on the Supreme Court between 1993 and 1996 concluded that no gender difference existed in cases dealing with legal rights but that the female justices were more supportive than their male colleagues of rights claimants in cases involving fundamental freedoms and equality rights. In contrast, in their analysis of criminal cases in Alberta, McCormick and Job (1993) found little difference in the output of male and female judges, even across issues like sexual assault. The differences that were found revealed that the women are slightly more conservative in criminal cases than their male colleagues.

Other recent studies provide a more comprehensive analyses of votes in both Charter and non-Charter cases. Ostberg and Wetstein (2007) in examining all nonunanimous votes by the justices on the Supreme Court of Canada in civil liberties cases from 1984-2003, found that after controlling for a measure of justice ideology analogous to the newspaper ideology scores widely used in studies of the U.S. Supreme Court (see Segal and Cover 1989) and for the party of the appointing prime minister, female justices were more likely than their male colleagues to support liberal outcomes in equality cases and in free speech areas (2007, 133 and 149). They did not examine gendered voting in criminal cases or economic cases, however.

Using a somewhat longer period, Songer and Johnson (2007) found that female Canadian Supreme Court justices were significantly more likely than their male colleagues to support a liberal outcome in non-unanimous votes in civil liberties cases. However there were no significant gender differences in economic cases. A more extensive analysis of voting on the Supreme Court of Canada from 1982-2003, found that after controls were introduced for the party of the appointing prime minister, religion, and region, there were significantly different voting patterns of male and female justices in three large policy areas (Songer 2008). Female justices were significantly more likely than their male colleagues to support rights claimants and economic underdogs but were less likely to support criminal defendants.

As this overview of previous studies demonstrates, the results from previous empirical studies of the effects of gender on judicial voting are decidedly mixed. However, evaluating the conflicting claims is made difficult by the failure of most of the previous studies to adequately specify the context in which these decisions by male and female judges took place. Most importantly, none of the cited studies considered whether the existence of a critical mass of women on a given court or the failure of female representation to reach the level of a critical mass may have impacted the patterns of decisions rendered by male and female judges.

\section{Critical Mass Theory}

While the literature on critical mass gender theory is relatively scant in the field of judicial politics, there have been a number of studies related to critical mass in the context of legislative politics. Critical mass theory largely developed after Kanter's (1977) study of corporate decision-making of groups in an organizational context. Kanter classified groups into four categories with corresponding percentages of the minority group as an explanation of group culture. Uniform groups contained only members of the majority population while the group containing less than 15 percent of 
the minority population was labeled the token group. The tilted group, whereby the minority population began to influence group culture, constituted 15 to 40 percent, and finally, groups with higher ratios of the minority population, 40 or 50 percent, were considered balanced groups. Building on this organization theory in the political world, Dahlerup (1988) applied a similar theoretical framework to Scandinavian politics. She proposed 30 percent as the figure to achieve a critical mass of females in legislatures and argued that reaching a critical mass of women in legislatures would result in changes of policy, political discourse, political culture, performance and efficiency, reaction, and power. However, in studying these outcomes across five legislative bodies, Dahlerup (1988) concluded that only in the political climate do direct changes occur with increased minority membership.

Building on Daherup's (1988) work, several scholars have examined parliaments where increasing numbers of female members have been elected. Grey (2006) examined the textual content of childcare, pay equity, and parental leave debates of the New Zealand legislature for a period from 1970 to 2005 to determine whether a critical mass of women MP's impacted the content of legislative discussion. Drawing on Dahlerup's (1988) earlier work, she found that a 15 percent threshold of women MP's had an impact on the policy agenda; however, reaching the 30 percent critical mass level did not have a substantial effect on policy or political culture. She concluded that the 30 percent critical mass level is not necessary to reach in order to affect policy change, and "that critical mass is only useful if we discard the belief that a single proportion holds the key to all representation needs of women and if we discard notions that numbers alone bring about substantive changes in policy processes and outcomes" $(2006,492)$. Other studies have found substantive changes in applying critical mass theory, concluding that legislatures with high proportions of women introduce and pass more bills related to women's issues than do legislatures with low proportions of women (Saint-Germain 1989; Thomas 1994). Bratton (2005) also found that higher numbers of women on state legislatures influenced both women's and men's support for women's issues. Norris and Lovenduski (2001) studied Britain's legislature as its female composition moved to Kanter's 'tilted' category in 1997 from simply a 'token' group in 1992, with roughly 18 percent of seats held in 1997 by females. When controlling for party, they did not find support of overall differences between male and female legislatures on most issues, including crime, censorship or redistribution of income. Norris and Lovenduski (2001) did however, find differences in males and females on women's issues such as abortion and equality, concluding that a critical mass did have an effect on policy issues of importance to women. Other studies have concluded that policy changes can be achieved with fewer numbers of women (Reingold 2000; Towns 2003), with some studies concluding that fewer numbers of women are more effective in the legislative context because they are perceived as less threatening to a dominant male agenda (Crowley 2004; Dodson and Carroll 1991).

To counter the importance of critical mass, Tremblay (2006), in examining the literature on parliamentary systems argues that “... a critical mass of women in politics does not necessarily translate into substantive representation of women, since this latter depends on many factors, such as gender identity, party affiliation, and the legislative roles of women” (2006, 509). In a later article, Dahlerup (2006) differentiates between the "politics of workplace perspective" where she reasserts that the 30 percent figure is 
useful, and the "policy outcomes perspective," where researchers have failed to identify a particular set number or percentage as a "critical mass.” Dahlerup (2006) emphasizes that the "critical mass" concept remains useful despite lack of consensus as to a particular percentage that constitutes a critical mass in certain contexts. In fact, she argues that more research is needed in this area to determine the number necessary for women to make a difference and the type of difference it makes.

For the purposes of this study, it is possible that in the appellate court context, we would see the two perspectives discussed by Dahlerup (2006) as less distinct and more blended, and that the small group dynamics might require a lower figure than 30 percent to constitute a critical mass for decision outcomes. Court research that has examined critical mass theory is much more limited than legislative research. The reason is straightforward. In the legislative arena, females have simply gained a number of seats that would constitute a critical mass at a faster rate than females in the judicial arena. There have been a handful of studies in the United States that examine critical mass theory in the judicial arena. Massie, Johnson, and Gubala (2002) found that at in the federal appeals courts, existence of a female on a three-judge panel influenced male decision-making patterns to a statistically significant degree. McCall (2002) found that in state supreme courts, male judges were more likely to decide search and seizure issues in a liberal manner when a female judge was on the panel. Peresie (2005) found that when a female was present on a federal appeals court panel, the panel was more than twice as likely to find a Title VII sex discrimination or sex harassment violation for the 1999-2001 period. Finally, Manning and Carp (2005) found that at the federal district court level, where at least two women served at a court point in the same U.S. city, female judges were likely to decide cases more liberally than were women in cities where at least two women were not serving at the same court point.

In the analysis below, we first attempt to resolve the conflict apparent from previous studies over the extent to which male and female judges do tend to vote differently by extending the analysis of Supreme Court justices from the date at which the first female justice joined the court through the end of the 2007 term. These results are then compared to an analysis of voting on the courts of appeal in five provinces. After examining the base question of whether there are different patterns of outcomes supported by male versus female justices, the analysis below then turns to the question of whether or not any gender differences discovered are dependent on the existence of a "critical mass" of female judges on the court.

\section{Data and Methods}

The analysis below compares the voting of male and female judges at the national Supreme Court level and the intermediate appellate court level in Canada. While a modest number of previous analyses have explored the significance of gender for judicial voting, the results are uneven and often difficult to compare because different studies have examined different courts, different time periods, and have employed different methodological approaches. The current study applies a common methodology to examine the decisions in the major issue areas with political salience across several different courts. If gender is a significant contributor to the differences discovered in previous studies, then those differences should remain consistent across courts.

The Attitudinal Model holds that justices make legal decisions based on their own “ideological attitudes and values" (Segal and Spaeth 1993, 73). While the theory behind the 
attitudinal model was developed in the context of voting on the Supreme Court of the United States, there is substantial evidence that the political preferences of the justices have a substantial impact on the outcomes of judicial decisions in Canadian appellate courts as well (Peck 1964; Fouts 1969; Tate and Sittiwong 1989; Heard 1991; Ostberg et al. 2002; Ostberg et al. 2004; Songer and Johnson 2007; Ostberg and Wetstein 2007; Songer 2008).

Ostberg and Wetstein note that a "principal reason for believing that Canadian justices would engage in the same degree of attitudinal decision making as their US counterparts stems from the political transformation that the Court experienced at the time of the Charter's enactment $(2007,30)$. Moreover, they suggest that the fact that prominent politicians, legal scholars, and journalists have leveled sharp criticism at the political nature of many of the Court's decisions since 1984 "leads credence to the contention that attitudes and values may be exerting the same degree of influence on the post-Charter Canadian Court as on the US Court” (2007, 31).

In order to provide a convincing comparison of the voting trends of male and female judges, it is essential to limit analysis to courts and time periods during which male and female judges served together. Such a limitation is necessary to insure that the agenda of cases decided by male and female judges are comparable. Thus, we limit analyses to periods in which there was at least one woman on each court. Consequently, the years chosen for analysis are slightly different for the different courts. The first female justice was appointed to the Canadian Supreme Court (Bertha Wilson) in 1982 and there has been at least one woman on the Court from that period to the present. Thus, our analysis of the Supreme Court of Canada runs from March 4, 1982 through the end of the 2007 term. The Supreme Court had bi-partisan membership throughout this period. For the courts of appeal of the five provinces included in this analysis (British Columbia, Alberta, Ontario, Quebec, and New Brunswick) we similarly limited analysis to periods in which the court had bi-partisan membership and at least one female judge.

For the Supreme Court, we test whether female justices will exhibit more liberal tendencies than male judges in four broad issue domains: equality and discrimination cases, private economic cases (e.g., torts), criminal law, and a combined category of civil liberties cases that excludes criminal appeals. Both the equality and the other civil rights categories include both statutory and constitutional claims. The criminal category includes appeals of convictions, ${ }^{4}$ procedural claims raised in criminal cases, postconviction relief, and habeas corpus petitions and it also includes cases raising both constitutional and non-constitutional claims. The votes of the justices are coded "one" for liberal votes and "zero" for conservative votes.

Demands for equal treatment, economic disputes, civil liberties, and criminal cases represent a broad range of judicial decision making from which to test the impact of judge gender on voting behavior. Together, these four issue domains appear to include a large majority of appellate court decisions that can be classified unambiguously as presenting a choice between liberal versus conservative outcomes. ${ }^{5}$

\footnotetext{
4 The Canadian data also includes appeals from acquittals. Such appeals are not possible in the United States because of the interpretations of the constitutional prohibition against double jeopardy.

${ }^{5}$ We also examined the voting behavior of female versus male judges on cases involving government economic regulation and labor relations, but found no significant gender differences on either court.
} 
We define a "liberal" outcome in the conventional manner, consistent with the definitions used in prior work on the effects of judge gender (e.g., see Ostberg and Wetstein 2007; Songer, Davis and Haire 1994; Walker and Barrow 1985; Songer and Crews-Meyer 2000) For instance, a vote in favor of a criminal defendant in criminal cases, a vote in favor of the party asserting that they were denied equal protection, or a vote in favor of a person alleging that their civil liberties were violated, and the plaintiff in tort actions all were coded as reflecting a liberal position. Our definition of a "liberal" outcome in a case is also consistent with coding used in studies of the Supreme Court of Canada (Tate and Sittiwong 1989).

The data for the analyses come from several sources. The national top court data include the universe of orally argued, formally decided case reported in the published decisions of each of the courts. The Canadian Supreme Court data come from the Comparative Courts High Court Database. ${ }^{6}$ The unit of analysis for each dataset was the opinion of the Court. The data for the decisions of the five provincial courts of appeal were collected by the authors, using the same coding definitions as those employed in the HCJD. The data, which were originally collected for a different project, included a random sample of 30 criminal cases per provincial court per year from 1982 through 2000. All of the Charter of rights cases decided by those same courts were also coded for the years 1982-2000. From these cases, we include in the analysis only those cases decided in years in which there was at least one woman on the court. ${ }^{7}$

Due to the dichotomous nature of the dependent variable, a series of logistic regressions were used in the analysis. The first series of models consist of our base models which attempt to answer the initial question of whether gender affects justice and judge decisions. We first run a series of models based on the Supreme Court data followed up with an analysis of the Courts of Appeal. The variable of interest in these models is gender, coded as "one" for male judges and "two" for female judges. The provinces are treated more as regions in this series of models, with Ontario and Quebec representing their own regions and the region "west” consisting of all provinces to the west of Ontario and the east or Atlantic Provinces being all of those east of Quebec. Dummy variables were created for each region with "two" indicating the presence of the region and "one" indicating its absence. We exclude the region "east" which consists of the Atlantic Provinces. We control for region here due to the fact that decisions may be colored by what region a justice or judge originates from. The ideology of Québécois, for example, is often argued to be more communitarian than other regions, while the western provinces tend to exude a more conservative, small government ideology. Party

\footnotetext{
${ }^{6}$ The Canadian data includes the universe of decisions published in the Canadian Supreme Court Reports for the years 1982-2007. The data through 2003 are part of a larger project, The High Courts Judicial Database (HCJD), funded by the National Science Foundation, "Collaborative Research: Fitting More Pieces into the Puzzle of Judicial Behavior: a Multi-Country Database and Program of Research,” SES9975323; and "Collaborative Research: Extending a Multi-Country Database and Program of Research," SES-0137349, C. Neal Tate, Donald R. Songer, Stacia Haynie and Reginald S. Sheehan, Principal Investigators. The data can be downloaded from the JURI project at the University of South Carolina. Website: http://cas.sc.edu/poli/juri The authors coded all of the decisions from 2004 through 2007 following the same coding scheme.

${ }^{7}$ For British Columbia, that meant cases decided between 1984 and 2000 ; for Alberta cases decided between 1985 and 2000 ; for Ontario, cases decided from 1987-2000 (Bertha Wilson was appointed to the Ontario court in 1976 but left in 1982 to take her seat on the Supreme Court); for Quebec, cases decided between 1986 and 2000; and for New Brunswick, cases decided from 1997 and 2000.
} 
is defined as the party of the prime minister that appointed each justice or judge. Party has been found in several previous studies to be strongly related to the votes of justices and judges. For this reason, we control for party as defined above.

The data is subsetted based on the type of case heard. For the Supreme Court data, cases are broken down into those dealing with issues of equality, all civil liberties excluding criminal cases, criminal cases, and private economic issues. As noted above, women have been found to vote in a more liberal direction on the civil liberties and private economic cases, but more conservatively on criminal cases. For the Appellate Court data, two additional models are run, using civil liberties cases in the first and criminal cases in the second.

The second series of models is an attempt to show support for Critical Mass Theory. In the Supreme Court models, rather than using gender as the variable of interest, we replace it with the number of women on the court at the time of judgment. The variable, number of females, ranges from one, in which there is only a single woman on the court and no female colleagues, to four in which a justice has the company of three female colleagues. In the Appellate Court models, we look at both the number of women on a panel, and the percentage of women judges in a given province at the time a decision is made. The control variables, party and region of origin remain the same in this series of models. The data is also subsetted in the same manner as above for the Critical Mass models.

\section{The Base Model of Gender Difference}

We begin our analysis of potential differences in patterns of decision making by female and male judges by examining voting tends on the Supreme Court of Canada. As noted above, to insure that we are comparing the votes of male versus female justices on the same cases, analysis is restricted to the period in which at least one woman sat on the Court (i.e., beginning at March 4, 1982 when Justice Bertha Wilson took her seat). We begin by examining the issue in which previous studies have most frequently discovered gendered differences in judicial voting: cases involving claims of the violation of the right to equality.

\section{Table 1 here}

The results of the logistic regression are presented in Table 1 . The most immediate impression from these results is that judicial characteristics that previous studies have found to be strongly related judicial voting (e.g., see Tate \& Sittiwong 1989) fail to reach statistical significance once a control is added for judge gender. Neither the political party of the justice nor the regional origins of the justice appear to be related to whether the justice supports pro or anti rights claimant positions. ${ }^{8}$ In contrast, the results confirm the findings of previous studies that female justices are substantially more likely than their male colleagues to support liberal (i.e., pro-rights claimant) outcomes. The relationship is significant at the .01 level.

\section{Table 2 here}

We next expanded the analysis to include votes in all cases involving civil liberties and rights claims other than those raised in the context of criminal proceedings. The data analyzed in Table 2 thus include cases involving the equality claims included in

\footnotetext{
${ }^{8}$ Some previous studies have examined regional effects by dichotomizing regional origins into those justices appointed from Quebec versus all others. When the table was re-run with this dichotomous regional variable, region remained unrelated to judicial choice.
} 
Table 1 along with assorted other rights claims including those involving freedom of expression, freedom of religion, privacy, language rights, and the rights of indigenous people. In this larger category of cases, earlier findings that the party of the appointing prime minister is significantly related to judicial choices is confirmed. Justices appointed by Liberal Party prime ministers are significantly more likely than justices appointed by Progressive Conservative Party leaders to support pro-rights outcomes. However, as in Table 1, regional origins are not related to voting choices. However, once again, judge gender appears to make a difference in the voting of the justices. Even with controls for party and region, female justices were substantially more likely than male justices to support liberal (i.e., pro-rights) outcomes.

\section{Table 3 here}

We next applied the same basic logistic regression model to the large number of criminal appeals heard by the Supreme Court. The results are presented in Table 3. Overall provide strong confirmation of previous studies (e.g., Tate \& Sittiwong 1989; Songer 2008) of judicial voting in Canada. Partisan effects are clearly evident. Judges appointed by Liberal Party prime ministers are substantially more likely than those appointed by Conservative Party prime ministers to support pro-defendant outcomes. The differences are significant at the .001 level. Similarly, regional differences loom large. Justices from the West and from Ontario are substantially more likely than justices from the East (the excluded category in the model) to support pro-defendant outcomes. Notably, however, even after controlling for these strong regional and partisan effects, judge gender appears to affect the trends in judicial voting. As noted in previous studies (Songer and Johnson 2007; Songer 2008), female justices in Canada were substantially more likely than their brethren to support pro-prosecution outcomes. In contrast to gender studies of judicial voting in the US that either have found no differences in criminal cases between male or female judges or have found female judges more likely to support a pro-defendant position, female justices on the Supreme Court of Canada appear to manifest support for a communitarian perspective that stresses the need to protect the interest of the larger society to be free from criminal actions that tend to break down the bonds that hold the community together.

\section{Table 4 here}

The final area of Supreme Court decision making examined included private economic conflicts pitting the "have nots" of society against corporations and wealthy groups. The analysis is presented in Table 4 . Since such economic strife is often central to division among political parties in the larger political sphere, it is noteworthy that there is no significant relationship between the party of the appointing prime minister and judicial outcomes. In fact, there is a slight tendency for justices appointed by Liberal Party prime ministers to be less supportive of outcomes favoring the "have nots." Regional differences are also not significantly related to the pattern of outcomes although there may be a slight tendency of justices from the Atlantic provinces to be the most supportive of the "have nots." However, once again, gender effects are apparent. Female justices are substantially more supportive than their male colleagues to support the "have nots.”

In summary, there were significant differences between the voting tendencies of female and male justices on the Supreme Court in all four issue areas examined. In fact, 
taken together, the results suggest that in the post-Charter period, gender may be the most important source of cleavage on the Supreme Court. ${ }^{9}$

As noted above, since the sample of decisions of the courts of appeal was originally collected for a different project, it was impossible to replicate the analysis of voting on the intermediate in all four issue areas. Additionally, the proportion of the intermediate courts' dockets consisting of cases raising equality claims is so small that is difficult to collect an adequate sample of such cases. Therefore, our analysis of decisions in the courts of appeal is limited to the broad category of all rights cases and to criminal appeals. As in our analysis of decision making on the Supreme Court, we limit analysis to those years in which there was at least one woman serving as a judge on the provincial court. ${ }^{10}$ Thus, the cases do not come from the same years for different provinces.

\section{Table 5 here}

We begin with the analysis of decisions in the sample of civil liberties and rights cases heard by the intermediate courts. The results are displayed in Table 5. In contrast to both the results of previous studies of voting on the Supreme Court of Canada and the results presented above in the present study, there appear to be no systematic relationships between the attributes of the judges and the patterns of outcomes they support. Overall, the model including the party, gender and regional origins of the justices is not statistically significant. Additionally, none of the variables in the model is related to judicial votes to a statistically significant degree. Although the sign of the relationship between gender and support for liberal outcomes is in the expected direction, the relationship falls well short of reaching conventional levels indicating statistical significance.

\section{Table 6 here}

For the final step in our examination of overall patterns of gendered voting, we turn to decisions in the criminal appeals heard by Canada's intermediate appellate courts. The results are presented in Table 6. Overall, the model is significant at the .001 level. However, none of the judicial attributes are strongly related to judicial voting trends. There is some support however, for the expectations derived from the analysis of Supreme Court voting. Most notably, the relationship between judge gender and support for criminal defendants is negative as expected (i.e., women are more likely to support the prosecution) and falls just short of conventional levels of statistical significance (specifically $\mathrm{p}=.06$ ).

Considering all of the analyses of judge gender presented above, we have a somewhat mixed picture. We found strong relationships between the gender and voting patterns of justices on the Supreme Court, but only weak relationships on the courts of appeal. The patterns on the lower court do not directly contradict the patterns on the Supreme Court - on both courts the direction of the relationships are the same. But the

\footnotetext{
${ }^{9}$ However, it is important to keep in mind when evaluating these results or other studies of the bases of cleavage on the Supreme Court of Canada, that in nearly three-fourths of all decisions, the Court was unanimous. Thus, even though gender differences among the justices reach levels of statistical significance, in a substantial majority of cases all female justices join with all male justices to produce a unanimous decision.

${ }^{10}$ We do not limit analysis to cases in which there was both a male and a female judge on the panel in question. In each province, interviews by the authors with a sample of judges indicated that cases are assigned to panels in a manner that is essentially random. Thus, there is no reason to believe that the overall sample of cases heard by male judges is different fro the sample of cases heard by female judges.
} 
relationships between gender and voting is simply quite weak on the intermediate court. While the data themselves provide no direct evidence for why we should find these differences in the patterns on the two courts, we offer two, admittedly speculative possible reasons for the differences. First, since 1975, the Supreme Court largely controls its own docket. Interviews with the justices by the authors indicate that the Court limits its docket primarily to cases raising controversial and/or important questions of policy, legal issues not previously decided by the Court, and cases raising legal issues on which the provincial courts are divided. Thus, by their nature, the Supreme Court primarily hears cases with no clear answers; that is to say cases in which the justices have substantial amounts of discretion about how to resolve the dispute and frame the new legal rule. In such cases one might anticipate that factors including gender that might influence the justices political preferences and/or their approach to jurisprudence will have substantially greater impact than they would in cases raising more clear cut legal issues and well established precedents. In contrast, since the provincial courts have little docket control, in many of their cases the justices are likely to be constrained by relatively clear law that will limit the impact of judicial socialization and preferences.

A second possible reason for differences discovered between the intermediate court and the Supreme Court may have to do with unofficial norms of decision making. On the courts of appeal, there appears to be a stronger norm supporting consensus than is found on the Supreme Court. Moreover, it is empirically easier to reach consensus on a panel with three members rather than 9 members. The intermediate courts are unanimous in $92 \%$ of the cases in our sample. Given this tendency to unanimity it is more difficult to determine the impact of factors such as gender that may influence the preferences of judges with the result that gender differences that are in fact present may not show up or be cancelled out by the "noise" of unanimity.

\section{Testing Critical Mass}

Theoretically, any effects from the presence or absence of a critical mass of female judges will be visible only in the change in voting by female judges. Thus, the basic test of critical mass theory is whether or not the behavior of the female judges on a court changes as the number or proportion of their female colleagues increases. If critical mass theory is applicable to judicial decision making, it may manifest itself in one of two different ways. First, the tendency of a given female judge to express her preferences that are related to her gendered socialization may gradually increase as the number of female colleagues on her court increases. In this scenario, one would expect a linear relationship between the number of female colleagues and the tendency of the given judge to vote along gender lines. Alternatively, the idea of a critical mass may take the form of a threshold effect. That is, a lone female judge may be inhibited from voicing her true preferences because of a strategic concern about the way in which her male colleagues may respond to such an expression. Such a judge may only publicly express her true preferences once the number of her female colleagues has reached some specific level. The literature reviewed above provides no clear expectation about the precise percentage of female judges that are necessary to constitute a "critical mass." Therefore, we will empirically explore how many justices are necessary before a critical mass is reached or whether there in reality is no such effect. To do this, we will sequentially test all of the possible threshold effects. Since the Supreme Court has only nine justices, the only possible values for establishing a threshold effect that is less than a majority of the 
court are the existence of one, two, three, or four female justices. Thus, we will sequentially create a dichotomous variable for the existence of a critical mass that will take the values one, two, three, and four.

\section{Table 7 here}

We first test the possibility that a critical mass is theoretically understood as having an incremental effect on the voting of female justices that increases as the number of females on the court increases. Our first test, presented in Table 7, examines the votes of female justices of the Supreme Court on cases raising equality issues. The key variable of interest is the effect of the total number of female justices on the court. If critical mass theory is correct, then this variable should be significantly related to the tendency of female justices to vote consistently with the expectations about gendered voting. We again control for the effects of political party and region. ${ }^{11}$ The results indicate that the number of female colleagues has no measurable effect on the likelihood of a female justice to support a rights claimant in equality cases. As noted in Table 1, overall, female justices are more likely than male justices to support the rights claimant. However, this tendency is NOT greater when a given female justice has one or more female colleagues. In fact, the sign of the coefficient for number of female justices is negative, indicating that there is a slight (but statistically not significant) tendency for female justices to become less likely to support rights claimants as additional female justices join them on the court.

\section{Table 7a here}

We next tested the possibility that the idea of a critical mass was essentially a threshold function. To do that we created three dichotomous variables defining the threshold for a critical mass first at two female justices or $22 \%$ of the Court's membership (i.e., comparing one female justice voting with no female colleagues the effect of having one or more female colleagues), then at three female justices (33\% of the court) and finally at four female justices (44\% of the Court - the largest percentage of female justices empirically serving on the Court at any one time). The results are presented in Table 7a. A glance at the table indicates the effect of a critical mass defined as a threshold effect in this manner (i.e., one vs 2 or more females) produces results that are essentially no different from examining the incremental impact of each additional female justice (see table 7 above). As in the previous example, the impact of the number of female colleagues on the probability that a given female justice will support the rights claimant is statistically insignificant and even in the direction opposite to the expectation created by a theory of critical mass.

We then repeated the analysis presented in Table 7a for two additional cut off points to define the existence of a critical mass (i.e., one or two females vs more than two and three female justices or under vs four female justices). The results (not presented) are essentially the same as those in Table 7a. That is, increasing the number of female colleagues above either of the hypothesized threshold levels produces no significant change in the tendency of female justices to support rights claimants.

\footnotetext{
${ }^{11}$ Given the small number of female justices who have served on the Supreme Court of Canada (7), there was too high a level of multicollinearity to permit the testing of a four part division of region. Thus, we control for region using a dichotomous variable indicating whether the regional origin of the justices was from Quebec or from one of the other provinces.
} 


\section{Table 8 here}

We next repeated the analysis for female votes in the sample of all civil rights and liberties cases. We again began by examining the possibility that a critical mass is theoretically understood as having an incremental effect on the voting of female justices that increases as the number of females on the court increases. The results displayed in Table 8 are similar to the tests of critical mass in equality cases described above. That is, there is virtually no relationship between the number of women on the Court and the probability that a given female justices will support a pro-rights claimant outcome. The coefficient for the number of female justices is near zero and fails to reach statistical significance.

After failing to find any effect for the idea of a critical mass understood as a an ordinal variable, we tested the effect of each of the three possible cut off points for critical mass understood as involving a threshold effect. The results (not presented) are very similar to the results of the similar analysis for equality cases. In all three iterations, achieving the hypothesized threshold number of female justices had substantively small and statistically insignificant effects on the likelihood of a pro-rights claimant vote by female justices.

\section{Table 9 here}

Our third test of the effects of a hypothesized critical mass involved running the same models of judicial decision making for female justices in criminal appeals. The results for the model of critical mass as an ordinal variable are presented in Table 9. The results demonstrate while women are more likely to support criminal defendants if they were appointed by a Liberal Party prime minister or came to the Court from some province other than Quebec, the number of female colleagues they have on the Court has virtually no relationship to their voting behavior.

When the three tests of the effect of critical mass conceptualized as a threshold effect (e.g., having no female colleagues vs having either one, two, or three other women on the Court) are run, the results (not presented) again fail to support any effect of a critical mass. Regardless of how the threshold is defined, women who have more than the hypothesized threshold number of female colleagues are no more likely than women having fewer than the hypothesized number of female colleagues to support a proprosecutor outcome.

\section{Table 10 here}

Our final tests of critical mass at the level of the Supreme Court of Canada involved voting in private economic cases. The results for the model of critical mass as an ordinal variable are presented in Table 10. The results are essentially the same as in the other three issue areas. Increasing the number of female colleagues does not increase the chances of a vote by a female justice in support of economic underdogs. Likewise, when the three different threshold levels tested, the results again are the same in private economic cases as in the other three areas. There is no support for the idea that gender effects will be evident or more pronounced once some threshold of the number of female justices on the court is reached.

\section{Testing Critical Mass in the Courts of Appeal}

One potentially important difference in the context of decision making in the courts of appeals compared to that in the Supreme Court is that almost all decisions of the courts of appeal are made by panels of three judges drawn from a total court that is 
substantially larger than the size of the Supreme Court (e.g., currently there are more than twenty judges on the courts of appeal in at least three provinces- British Columbia, Ontario, and Quebec). Therefore, if the number of female colleagues has an important relationship to the voting of female judges it is possible that the relevant reference is either the total number of female judges on the provincial court as a whole or the number of female colleagues sitting on the particular panel. We tested separately for each possibility.

\section{Table 11 here}

Starting with cases raising civil liberties and civil rights claims, we first followed the procedure used in the Supreme Court, treating the concept of critical mass as an ordinal variable. The results are presented in Table 11. As can be seen from the analysis, neither the party of the appointing prime minister nor the regional origins of the judge have any significant effect on whether a female judges will support a rights claimant. Additionally, the results for the effect of the proportion of female judges on the provincial court as a whole paralleled those found in the Supreme Court. The number of female colleagues had no significant effect of the likelihood that a given female judge would support the rights' claimant.

As in the Supreme Court, the analysis was repeated to test the possibility that critical mass functions primarily as a threshold effect. Multiple potential thresholds were tested. We first examined the case in which a female justice had no female colleagues vs courts on which she had at least one female colleague. Then we examined the situation of the total number of females being under $10 \%$ vs courts with more than $10 \%$ female judges. We also examined setting the threshold at $20 \%$, at $30 \%$ and at $40 \%$. In every one of the separate tests of the effects of a discrete threshold for the number of female justices, the dichotomous variable representing the number of female judges was not related to the likelihood that a female judge would vote in favor of the rights claimant. Table 11a here

The analysis for the number of female justices on each court was then repeated for changes in the number of women serving on each panel. The results are displayed in Table 11a. Once again, changing the number of female colleagues has no significant effect on the likelihood that a given female judge will support an outcome favoring the rights claimant. There were no significant differences between the voting patterns of female judges who were the sole representative of their gender on the panel and those women who had one or two female colleagues.

\section{Table 12 here}

Next we performed the same analysis of courts of appeal decisions dealing with criminal appeals. We first began with conceptualizing a critical mass as an ordinal variable that might have an incremental effect on voting by female judges as the number of their female colleagues increased. The results of the analysis are presented in Table 12. The results in Table 12 provide the first, if somewhat weak, support for critical mass theory discovered in all of the analyses presented in this project. We saw in the analysis of base gender effects (see Table 3 above) that female judges were more likely than their male colleagues to support pro-prosecution outcomes. Thus, one would expect that once the number of female justices reached a "critical mass" there would be a more pronounced tendency of female judges to support pro-prosecution outcomes. The results in Table 12 provide at least weak support for this expectation. Specifically, the 
likelihood of a pro-prosecution vote by female justices does appear to increase as the number of female judges on the provincial court as a whole increases. This tendency is close to conventional standards of statistical significance $(\mathrm{P}=.08)$. However, the model as a whole is not statistically significant. Moreover, when each individual hypothesized threshold cut off for a critical mass was examined in subsequent analyses (not presented), none of the thresholds were related to the likelihood of a pro-prosecution vote to a statistically significant extent.

\section{Table 12a here}

As in the analysis of civil liberties cases, we followed up the analysis of the effects of increasing the number of females on the court as a whole with an analysis of changing the number of females on the particular panel deciding each case. The results are presented in Table 12a. These results provide no support for critical mass theory. The proportion of female judges on the panel deciding each case has no substantial relationship to the likelihood that a given female judge will support a pro-prosecution outcome.

Overall, then there is very little support for the idea that distinctive patterns of voting for female compared to male judges depend on the existence of a "critical mass" of judges on a court. That is, there appears to be no critical mass of female justices that once achieved encourages or facilitates voting by those female justices that is different from the way they actually vote when they have no female colleagues. On the Supreme Court of Canada, not a single one of the tests for any of the alternative ways to conceptualize the idea of critical mass produced any findings that were consistent with the idea that achieving a critical mass was necessary before gendered patterns of voting could appear among the justices. In tests of voting on the provincial courts of appeal, only one of the tests provided any support for a theory of critical mass, and the results of that test were quite weak.

\section{Discussion}

The results of our analysis confirm several previous findings regarding gender decision-making patterns in the Supreme Court of Canada. Ostberg and Wetstein (2004) found that female justices were more likely to favor the claimants' position in equality cases than were male justices. Studies of crucial mass theory in legislatures also suggest that it is largely in the realm of issues that are of immediate importance for women, that we would likely see the greatest policy impact of female representation (Norris and Lovenduski 2001). Similarly, in the context of civil liberties claims, female justices at the Supreme Court level are more likely to render liberal decisions and at the same time render conservative decisions in criminal cases, which also confirms the findings of previous studies (Songer and Johnson 2007, Ostberg and Wetstein 2008, Johnson 2008).

Our findings do not tend to support critical mass theory as a policy making outcome, however. There may be several reasons for this result. First, previous legislative studies, as we discussed earlier, have arrived at mixed results when it comes to policy making. Some studies have found that a critical mass of female legislatures does not necessarily lead to policy changes, but may, in fact, make a difference in group relationships, policy agendas, and overall political culture. It could be that the impact of females on appellate courts in Canada does not reveal itself as straightforwardly in policy making outcomes, as we have tested in this study. It could be that critical mass has an impact in more subtle ways. For instance, perhaps the agenda setting of the courts, 
through the use of discretionary docket control, has been impacted by a critical mass of female justices. In many ways selection of cases for review through the leave to appeal process is as much a function of small group interaction as is actual case outcomes. Here, presence of a female on the panel selecting cases for argument might make a difference in the types of cases selected for ultimate Supreme Court review. We know for example that the agenda of the Supreme Court has changed dramatically since the arrival of the first female justice. The number of criminal cases, especially those raising constitutional challenges to conviction has risen dramatically and the number of civil rights and liberties cases has more than tripled compared to the decade before the arrival of the first female justice (Songer 2008). Of course, the arrival of the first female justice on the Supreme Court also coincided with the adoption of the Charter of Rights; thus, it is difficult to determine the extent to which the changing agenda was due to the participation of female justices in the leave process and how much was due to effects of the Charter.

The adoption of the Charter at about the same time that the first female justice joined the Court may have an additional effect. Many of the perspectives that previous literature has suggested may be a part of the socialization of female judges also are enshrined in the Charter of Rights. We speculate that perhaps women judges in Canada don't really 'need' a critical mass to overcome the outsider role. They have the support of Canadian society at large, the political context and culture of the times, and interest groups who were bringing these cases to the Court after the Charter. They can be strong willed without relying on a critical mass of other females on the Court because they have the strongest institutional, cultural, social and political support in Canadian society than at any time before. That could be why we don't see a critical mass effect at either court level. To test this theory, we would need to look pre-Charter to find critical mass effects, but of course we can't because there aren't women on the courts at that time.

Another possibility is in opinion writing. Johnson (2008) found differences in the approach female justices, particularly L'Heureux-Dube, used in their opinions, finding that in criminal cases where the issue was a crime of violence against women, female justices were more likely to write a concurring opinion, even if their voting patterns did not differ substantially from male voting patterns. An examination of past dissents or concurring opinions by females justices and the impact of those on male opinion writing in subsequent cases of a similar nature, could provide some insight into the impact of female judges on the courts. Consistent with the critical mass literature, it is possible that the impact of females on the courts is much more subtle in some areas, and that the greatest amount of impact occurs prior to the stage of actual decision making on the merits, as measured simply by the votes cast rather than other more subtle measures of behavior.

Alternatively, it might be argued that women are even more likely to vote in a gendered manner when they are alone on the bench, since they might conclude that there is an obvious need for a woman's perspective in these cases. As these initial female judges gain female colleagues they feel less internal pressure to "represent" women and freer to vote sincerely according to their own personal perspectives which are of course shaped in part - but only in part- by their socialization and experiences as a woman. Moreover, as we see more and more women gaining access to positions of power whether 
in parliament, executive positions, or on the courts, it is possible that gender will become less salient an issue because women and men are being socialized in societies where gender roles are less defined. 


\section{References}

Abrahamson, Shirley S. 1993. “Toward a Courtroom of One’s Own: An Appellate Court Judge Looks at Gender Bias.” University of Cincinnati Law Review. 61: 1-14.

Aliotta, Jilda M. 1995. “Justice O’Connor and the Equal Protection Clause: A Feminine Voice?” Judicature 77:156-165.

Allen, David W., and Diane E. Wall. 1993. "Role Orientations and Women State Supreme Court Justices.” Judicature 77: 156-165.

Allen, David W., and Diane E. Wall. 1987. “The Behavior of Women State Supreme Court Justices: Are They Tokens or Outsiders?” Justice System Journal 12:232.

Bratton, Kathleen A. 2005. "Critical Mass Theory Revisited: The Behavior and Success of Token Women in State Legislatures.” Politics \& Gender 1: 97-125.

Cook, Beverly. 1981. Will Women Judges Make a Difference in Women's Legal Rights? A Prediction from Attitudes and Simulated Behavior. In Women, Power and Political Systems, edited by G. Ashworth. New York: St. Martin's Press.

Crowley, Jocelyn Elise. 2004. “When Tokens Matter.” Legislative Studies Quarterly 29: 109-36.

Dahlerup, Drude. 1988. "From a Small to a Large Minority: Women in Scandinavian Politics.” Scandinavian Political Studies 11: 275-98.

Dahlerup, Drude. 2006. “The Story of the Theory of Critical Mass.” Politics and Gender 2: 511-522.

Davis, Sue. 1993. “The Voice of Sandra Day O’Connor.” Judicature 77:134-139..

Dodson, Debra, and Sue Carroll. 1991. Reshaping the Agenda: Women in State Legislatures. New Brunswick, NJ: Center for American Women and Politics.

Fouts, Donald E. 1969. Policy Making in the Supreme Court of Canada, 1950-1960. In Glendon Schubert and David J. Danelski, eds., Comparative Judicial Behavior, New York: Oxford University Press, 257-291.

Gilligan, Carol. 1982. In a Different Voice: Psychological Theory and Women's Development. Cambridge: Harvard University Press.

Greene, Ian, Carl Baar, Peter McCormick, George Szablowski, and Martin Thomas. 1998. Final Appeal: Decision-Making in Canadian Courts of Appeal. Toronto: James Lorimer \& Company. 
Grey, Sandra. 2006. "Numbers and Beyond: The Relevance of Critical Mass in Gender Research.” Politics and Gender 2: 492-502.

Gryski, Gerard S., Eleanor C. Main, and William J. Dixon. 1986. Models of State High Court Decision Making in Sex Discrimination Cases. Journal of Politics 28:143-155.

Heard, Andrew D. 1991. "The Charter in the Supreme Court of Canada: The Importance of Which Judges Hear an Appeal.” Canadian Journal of Political Science, XXIV:2.

Johnson, Susan W., Ronald Stidham, Kenneth Manning, and Robert Carp. 2008. "The Gender Influence on U.S. District Court Decisions: Updating the Traditional Judge Attribute Model." Journal of Women, Politics \& Policy 29: 497-526.

Kanter, Rosabeth Moss. 1977. "Some Effects of Proportions on Group Life: Skewed Sex Ratios and Responses to TokenWomen.” American Journal of Sociology 82: 965-90.

Kuersten, Ashlyn, and Ken Manning. 2000. Women Judges on the Lower Federal Courts: Are They Different from Their Brethren? In Western Michigan University. Kalamazoo.

L'Heureux-Dube, Madame Justice Claire. 1997. Making a Difference: The Pursuit of a Compassionate Justice. In University of British Columbia Law Review.

McCall, Madhavi. 2002. "How Far Does the Gender Gap Extend? Decision-Making on State Supreme Courts in Fourth Amendment/Privacy Cases, 1980-2000.” Paper presented at the 2002 meeting of the Western Political Science Association.

Manning, Kenneth L. and Robert A. Carp. 2005. "Gender and Decision-Making in the Federal Courts: Testing the Critical Mass Theory.” Paper presented at the 2005 Annual Meeting of the American Political Science Association, Washington, DC.

Martin, Elaine. 1993a. “The Representative Role of Women Judges.” Judicature 77: 166173.

Martin, Elaine. 1993b. "Women on the Bench: A Different Voice?” Judicature 77: 126128.

Massie, Tajuana, Susan W. Johnson, and Sara M. Gubala. 2002. "The Influence of Gender and Race on Judicial Decisions in the United States Courts of Appeals.” Presented at the Midwest Political Science Association Meeting in Chicago, IL, April 2002.

McCormick, Peter, and Twyla Job. 1993. Do Women Judges Make a Difference? An Analysis of Appeal Court Data. In Canadian Journal of Law and Society.

Norris, Pippa and Joni Lovenduski. 2001. "Blair's Babes: Critical Mass Theory, Gender, and Legislative Life.” John F. Kennedy School of Government Harvard University Faculty Research Working Papers Series, September 2001. 
O'Connor, Karen, and Jeffery A. Segal. 1990. Justice Sandra Day O’Connor and the Supreme Court's Reaction to Its First Female Member. In Women and Politics.

Ostberg, C.L. and Matthew E. Wetstein.2007. Attitudinal Decision Making in the Supreme Court of Canada. (Vancouver: University of British Columbia Press).

Ostberg, C.L. and Matthew E. Wetstein. 2004. "Equality Cases and the Attitudinal Model in the Supreme Court of Canada." Presented at the Annual Meeting of the Canadian Political Science Association.

Ostberg, C.L., Susan W. Johnson, Donald R. Songer, and Matthew E. Wetstein. 2004. "The Nature and Extent of Attitudinal Conflict in the Supreme Court of Canada." Presented at the Annual Meeting of the American Political Science Association, Chicago.

Ostberg, C.L., Matthew E. Wetstein, and Craig R. Ducat. 2002. "Attitudinal Dimensions of Supreme Court Decision Making in Canada: the Lamer Court, 1991-1995” Political Research Quarterly 55 (\#1): 235-256.

Palmer, Barbara. 1991. Feminist or Foe? Justice Sandra Day O’Connor, Title Vii Sex Discrimination and Support for Women's Rights. In Women's Rights Law Reporter.

Palmer, Barbara. 2002. Justice Ruth Bader Ginsburg and the Supreme Court's Reaction to Its Second Female Member. In Women and Politics.

Peck, Sidney. 1969. A Scalogram Analysis of the Supreme Court of Canada, 1958 1967. In Glendon Schubert and David Danelski, eds., Comparative Judicial Behavior, New York: Oxford University Press, 293-334.

Peresie, Jennifer L. 2005. "Female Judges Matter: Gender and Collegial Decision Making in the Federal Appellate Courts.” The Yale Law Journal, vol. 114:1759.

Reingold, Beth. 2000. Representing Women. Chapel Hill: University of North Carolina Press.

Saint-Germain, Michelle. 1989. "Does Their Difference Make a Difference? The Impact of Women on Public Policy in the Arizona Legislature.” Social Science Quarterly 70: 956-68.

Segal, Jeffrey A. and Albert D. Cover. 1989. "Ideological Values and Votes of US Supreme Court Justices.” American Political Science Review 83:557-65.

Segal, Jeffrey Allan, and Harold J. Spaeth. 1993. The Supreme Court and the Attitudinal Model. Cambridge ; New York: Cambridge University Press.

Segal, Jennifer. 2000a. "Representative Decision Making on the Federal Bench: Clinton's District Court Appointees.” Political Research Quarterly. 53: 147-150. 
Segal, Jennifer. 2000b. “Are Men From Mars and Women From Venus? Judicial Decision Making on the Federal District Court Bench.” Paper presented at the Annual Meeting of the Midwest Political Science Association, Chicago, IL.

Sherry, Suzanna. 1986. "Civil Virtue and the Feminine Voice in Constitutional Adjudication.” Virginia Law Review 72: 582-583.

Songer, Donald R., and Ann Clark. 2002. Judge Gender and Voting in Appellate Courts: A Cross National and Cross Institutional Analysis. In Southern Political Science Association. Savannah, GA.

Songer, Donald R., and Kelley A. Crews-Meyer. 2000. Does Judge Gender Matter? Decision Making in State Supreme Courts. Social Science Quarterly 81:750-762.

Songer, Donald R., Sue Davis, and Susan Haire. 1994. A Reappraisal of Diversification in the Federal Courts: Gender Effects in the Courts of Appeals. Journal of Politics 56:425-439.

Songer, Donald R. and Susan W. Johnson. 2007. "Judicial Decision Making in the Supreme Court of Canada: Updating the Personal Attribute Model.” Canadian Journal of Political Science 40:911-934.

Songer, Donald R. 2008. The Transformation of the Supreme Court of Canada: An Empirical Examination. Toronto: University of Toronto Press.

Tate, C. Neal and Paul Sittiwong. 1989. Decision Making in the Canadian Supreme Court: Extending the Personal Attributes Model Across Nations.? Journal of Politics, $51: 4$

Thomas, Sue. 1994. How Women Legislate. New York: Oxford University Press.

Towns, Ann. 2003. "Understanding the Effects of Larger Ratios of Women in National Legislatures: Proportions and Gender Differentiation in Sweden and Norway.”Women \& Politics 25: 1-29.

Tremblay, Manon. 2006. “The Substantive Representation of Women and PR: Some Reflections on the Role of Surrogate Representation and Critical Mass.” Politics and Gender 2: 502-511.

Walker, Thomas G., and Deborah J. Barrow. 1985. The Diversification of the Federal Bench: Policy and Process Ramifications. Journal of Politics 47:596-617.

White, Candace C. 2002. “Gender Differences on the Supreme Court.” In Morton. F.L., ed. Law and Politics and the Judicial Process in Canada, $3^{\text {rd }}$ edition (Calgary: University of Calgary Press). 
Wilson, Bertha. 1990. Will Women Judges Really Make a Difference? In Osgood Hall Law Journal.

Woodruff, Judy. 2003. Sandra Day O’Connor: The Majesty of the Law. In CNN Exclusive Interview. 
Figure 1

Female Justices on the Supreme Court of Canada, 1875-2009

\begin{tabular}{|c|c|c|c|c|}
\hline \multirow[b]{2}{*}{ Justice } & \multicolumn{3}{|c|}{ Supreme Court of Canada } & \multirow[b]{2}{*}{ Party } \\
\hline & Appointed & $\begin{array}{l}\text { Left } \\
\text { Court } \\
\end{array}$ & $\begin{array}{l}\text { Prime } \\
\text { Minister } \\
\end{array}$ & \\
\hline Bertha Wilson & $3-4-82$ & $4-1-91$ & Trudeau & Liberal \\
\hline Claire L'heureux-Dub & $4-15-87$ & 7-1-02 & Mulroney & $\begin{array}{l}\text { Progressive } \\
\text { Conservative }\end{array}$ \\
\hline Beverley McLachlin & 3-30-89 & -- & Mulroney & $\begin{array}{l}\text { Progressive } \\
\text { Conservative }\end{array}$ \\
\hline Louise Arbour & $9-15-99$ & $6-30-04$ & Chretien & Liberal \\
\hline Marie Deschamps & 8-7-02 & -- & Chretien & Liberal \\
\hline Rosalie Abella & $8-30-04$ & -- & Martin & Liberal \\
\hline Louise Charron & 8-30-04 & -- & Martin & Liberal \\
\hline
\end{tabular}




\section{Table 1}

Logistic Regression Models of the Likelihood of a Pro-Rights Claimant Vote in Equality Cases by Justices on the Supreme Court of Canada, 1982-2007

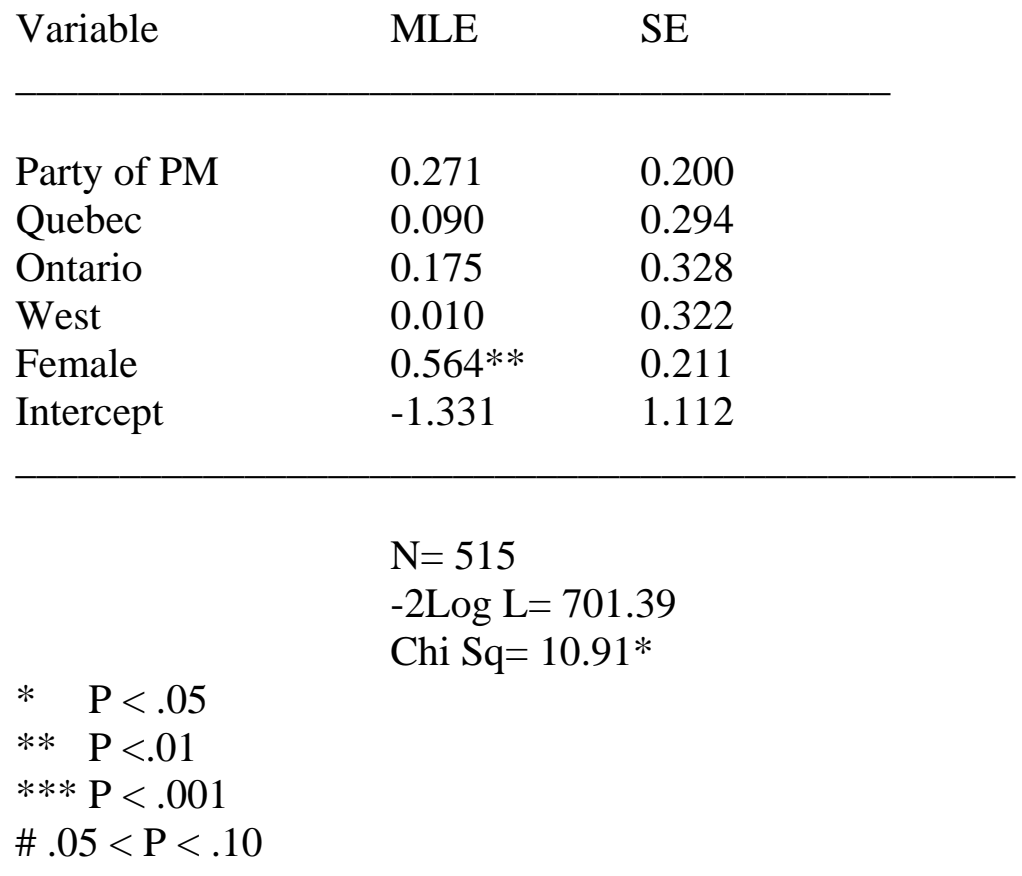




\section{Table 2}

Logistic Regression Models of the Likelihood of a Pro-Rights Claimant Vote in All civil Liberties cases by Justices on the Supreme Court of Canada, 1982-2007

$\begin{array}{lll}\text { Variable } & \text { MLE } & \text { SE } \\ & & \\ \text { Party of PM } & 0.270^{*} & 0.129 \\ \text { Quebec } & 0.176 & 0.198 \\ \text { Ontario } & 0.230 & 0.217 \\ \text { West } & 0.223 & 0.212 \\ \text { Female } & 0.309^{*} & 0.137 \\ \text { Intercept } & -1.642 & 0.735\end{array}$

$* \quad \mathrm{P}<.05$

$\mathrm{N}=1184$

$-2 \log \mathrm{L}=1627.82$

$* * \quad \mathrm{P}<.01$

$* * * \mathrm{P}<.001$

$\# .05<\mathrm{P}<.10$ 
Table 3

Logistic Regression Models of the Likelihood of a Pro-Defendant Vote by Justices on the Supreme Court of Canada, 1982-2007

\begin{tabular}{lll} 
Variable & MLE & SE \\
\hline & & \\
Party of PM & $0.380^{* * *}$ & 0.055 \\
Quebec & 0.170 & 0.089 \\
Ontario & $0.365^{* * *}$ & 0.094 \\
West & $0.307^{* * *}$ & 0.093 \\
Female & $-0.285^{* * *}$ & 0.061 \\
Intercept & \\
& \\
& \\
& \\
$\quad$ & $\mathrm{N}=6948$ \\
* $\mathrm{P}<.05$ & $\mathrm{Chog} \mathrm{L}=8995.86$ \\
$* * \quad \mathrm{P}<.01$ & \\
$* * * \mathrm{P}<.001$ & \\
$\# .05<\mathrm{P}<.10$ &
\end{tabular}




\section{Table 4}

Logistic Regression Models of the Likelihood of a Pro-Underdog Vote in Private Economic Cases by Justices on the Supreme Court of Canada, 1982-2007

$\begin{array}{lll}\text { Variable } & \text { MLE } & \text { SE } \\ & & \\ & & \\ \text { Party of PM } & -0.194 \# & 0.118 \\ \text { Quebec } & -0.178 & 0.181 \\ \text { Ontario } & -0.159 & 0.198 \\ \text { West } & -0.276 & 0.194 \\ \text { Female } & 0.223^{*} & 0.129 \\ \text { Intercept } & & \end{array}$

$$
\begin{aligned}
& \mathrm{N}=1385 \\
& -2 \log \mathrm{L}=1912.99 \\
& \text { Chi Sq= 6.64*** }
\end{aligned}
$$

$* \quad \mathrm{P}<.05$

$* * \quad \mathrm{P}<.01$

$* * * \mathrm{P}<.001$

$\# .05<\mathrm{P}<.10$ 
Table 5

Logistic Regression Models of the Likelihood of a Pro-Rights Claimant Vote by Judges on 5 Canadian Courts of Appeal, 1982-2000

\begin{tabular}{lcc} 
Variable & MLE & SE \\
\cline { 1 - 2 } & & \\
Party of PM & 0.249 & 0.225 \\
Quebec & 0.206 & 0.585 \\
Ontario & -0.104 & 0.576 \\
West & -0.068 & 0.610 \\
Female & 0.268 & 0.283 \\
Intercept & -0.964 & 0.592 \\
& & \\
\hline & $\mathrm{N}=417$ \\
& $-2 \mathrm{Log} \mathrm{L}=519.02$ \\
& $\mathrm{Chi} \mathrm{Sq}=3.09$ (NS) \\
* $\quad \mathrm{P}<.05$ & \\
$* * \quad \mathrm{P}<.01$ & \\
$* * * \mathrm{P}<.001$ & \\
$\# .05<\mathrm{P}<.10$ &
\end{tabular}


Table 6

Logistic Regression Models of the Likelihood of a Pro-Defendant Vote by Judges on 5 Canadian Courts of Appeal, 1982-2000

\begin{tabular}{lll} 
Variable & MLE & SE \\
\cline { 1 - 2 } & & \\
Party of PM & -0.121 & 0.051 \\
Quebec & 0.107 & 0.153 \\
Ontario & 0.009 & 0.153 \\
West & -0.217 & 0.150 \\
Female & $-0.099 \#$ & 0.063 \\
Intercept & -0.571 & 0.151 \\
& & \\
\hline & $\mathrm{N}=7418$ \\
& $-2 \mathrm{Log} \mathrm{L}=9354.33$ \\
& $\mathrm{Chi} \mathrm{Sq}=41.62 * * *$ \\
* $\mathrm{P}<.05$ & \\
$* * \quad \mathrm{P}<.01$ & \\
$* * * \mathrm{P}<.001$ & \\
$\# .05<\mathrm{P}<.10$ &
\end{tabular}




\section{Table 7}

Testing Critical Mass: Logistic Regression Models of the Likelihood of a Pro-Rights Claimant Vote in Equality Cases by Female Justices on the Supreme Court of Canada, 1982-2007

Variable

MLE

0.188

$-0.048$

$-0.188$

Number of Female Justices

Intercept
$\mathrm{N}=160$

$-2 \log \mathrm{L}=213.697$

$* \quad \mathrm{P}<.05$

** $\mathrm{P}<.01$

$* * * \mathrm{P}<.001$

\#.05 $<\mathrm{P}<.10$
0.370

0.337

0.216 


\section{Table 7a}

Testing Critical Mass: Logistic Regression Models of the Likelihood of a Pro-Rights Claimant Vote in Equality Cases by Female Justices on the Supreme Court of Canada, 1982-2007

Variable

MLE SE

Party of PM

0.021

0.340

Quebec

$-0.036$

0.338

One vs two or more Female Justices

$-0.653$

1.188

Intercept

1.745

2.499

$* \quad \mathrm{P}<.05$

$\mathrm{N}=160$

$-2 \log \mathrm{L}=214.13$

$* * \quad \mathrm{P}<.01$

$* * * \mathrm{P}<.001$

$\# .05<\mathrm{P}<.10$ 


\section{Table 8}

Testing Critical Mass: Logistic Regression Models of the Likelihood of a Pro-Rights Claimant Vote in All Civil Liberties Cases by Female Justices on the Supreme Court of Canada, 1982-2007

\begin{tabular}{lrl} 
Variable & MLE & SE \\
\hline & & \\
Party of PM & 0.053 & 0.242 \\
Quebec & -0.248 & 0.230 \\
Number of Female Justices & -0.003 & 0.138 \\
Intercept & 0.424 & 0.570
\end{tabular}

$* \quad \mathrm{P}<.05$

$\mathrm{N}=343$

$-2 \log \mathrm{L}=472.24$

$* * \quad \mathrm{P}<.01$

$* * * \mathrm{P}<.001$

$\# .05<\mathrm{P}<.10$ 


\section{Table 9}

Testing Critical Mass: Logistic Regression Models of the Likelihood of a ProDefendant Vote by Female Justices on the Supreme Court of Canada, 1982-2007

\begin{tabular}{lcc} 
Variable & MLE & SE \\
\hline Party of PM & $0.747^{* * *}$ & 0.112 \\
Quebec & $-0.496^{* * *}$ & 0.117 \\
Number of Female Justices & 0.049 & 0.065 \\
Intercept & -1.222 & 0.271
\end{tabular}

$\mathrm{N}=1,817$

$-2 \log \mathrm{L}=2209.76$

Chi Sq= 96.80***

$* \quad \mathrm{P}<.05$

$* * \quad \mathrm{P}<.01$

$* * * \mathrm{P}<.001$

$\# .05<\mathrm{P}<.10$ 


\section{Table 10}

Testing Critical Mass: Logistic Regression Models of the Likelihood of a ProUnderdog Vote in Private Economic Cases by Female Justices on the Supreme Court of Canada, 1982-2007

\begin{tabular}{lrc} 
Variable & MLE & SE \\
\hline & & \\
Party of PM & -0.271 & 0.226 \\
Quebec & 0.219 & 0.229 \\
Number of Female Justices & -0.319 & 0.139 \\
Intercept & 0.960 & 0.573
\end{tabular}

* $\quad \mathrm{P}<.05$

** $\mathrm{P}<.01$

$* * * \mathrm{P}<.001$

$\# .05<\mathrm{P}<.10$

$\mathrm{N}=374$

$-2 \log \mathrm{L}=508.79$

Chi $\mathrm{Sq}=9.25^{*}$ 


\section{Table 11}

Testing Critical Mass: Logistic Regression Models of the Likelihood of a Pro-Rights Claimant Vote by Female Judges on 5 Canadian Courts of Appeal, 1982-2000

\begin{tabular}{lcc} 
Variable & MLE & SE \\
\hline Party of PM & -0.599 & 0.639 \\
Quebec & -1.285 & 1.628 \\
Ontario & -1.243 & 1.545 \\
West & -2.180 & 1.941 \\
\# of Female Justices on Court & 3.556 & 3.768 \\
Intercept & 0.220 & 1.592
\end{tabular}

$* \quad \mathrm{P}<.05$

$\mathrm{N}=70$

$-2 \log \mathrm{L}=88.99$

$* * \quad \mathrm{P}<.01$

$* * * \mathrm{P}<.001$

$\# .05<\mathrm{P}<.10$

Chi $\mathrm{Sq}=2.10(\mathrm{NS})$ 


\section{Table 11a}

Testing Critical Mass: Logistic Regression Models of the Likelihood of a Pro-Rights Claimant Vote by Female Judges on 5 Canadian Courts of Appeal, 1982-2000

\begin{tabular}{lcc} 
Variable & MLE & SE \\
\hline Party of PM & -0.535 & 0.633 \\
Quebec & -0.899 & 1.585 \\
Ontario & -1.002 & 1.521 \\
West & -1.156 & 1.647 \\
\# of Female Justices on Panel & -0.080 & 0.751 \\
Intercept & 0.615 & 1.709
\end{tabular}

$* \quad \mathrm{P}<.05$

$\mathrm{N}=70$

$-2 \log \mathrm{L}=89.95$

$* * \quad \mathrm{P}<.01$

Chi Sq= $1.24(\mathrm{NS})$

$* * * \mathrm{P}<.001$

$\# .05<\mathrm{P}<.10$ 


\section{Table 12}

Testing Critical Mass: Logistic Regression Models of the Likelihood of a ProDefendant Vote by Female Judges on 5 Canadian Courts of Appeal, 1982-2000

\begin{tabular}{lcc} 
Variable & MLE & SE \\
\hline Party of PM & -0.035 & 0.139 \\
Quebec & 0.556 & 0.416 \\
Ontario & 0.510 & 0.414 \\
West & 0.464 & 0.411 \\
\# of Female Justices on Court & $-0.658 \#$ & 0.474 \\
Intercept & -1.084 & 0.403
\end{tabular}

$* \quad \mathrm{P}<.05$

$\mathrm{N}=1,567$

$-2 \log \mathrm{L}=1935.42$

$* * \quad \mathrm{P}<.01$

$* * * \mathrm{P}<.001$

$\# .05<\mathrm{P}<.10$ 


\section{Table 12a}

Testing Critical Mass: Logistic Regression Models of the Likelihood of a ProDefendant Vote by Female Judges on 5 Canadian Courts of Appeal, 1982-2000

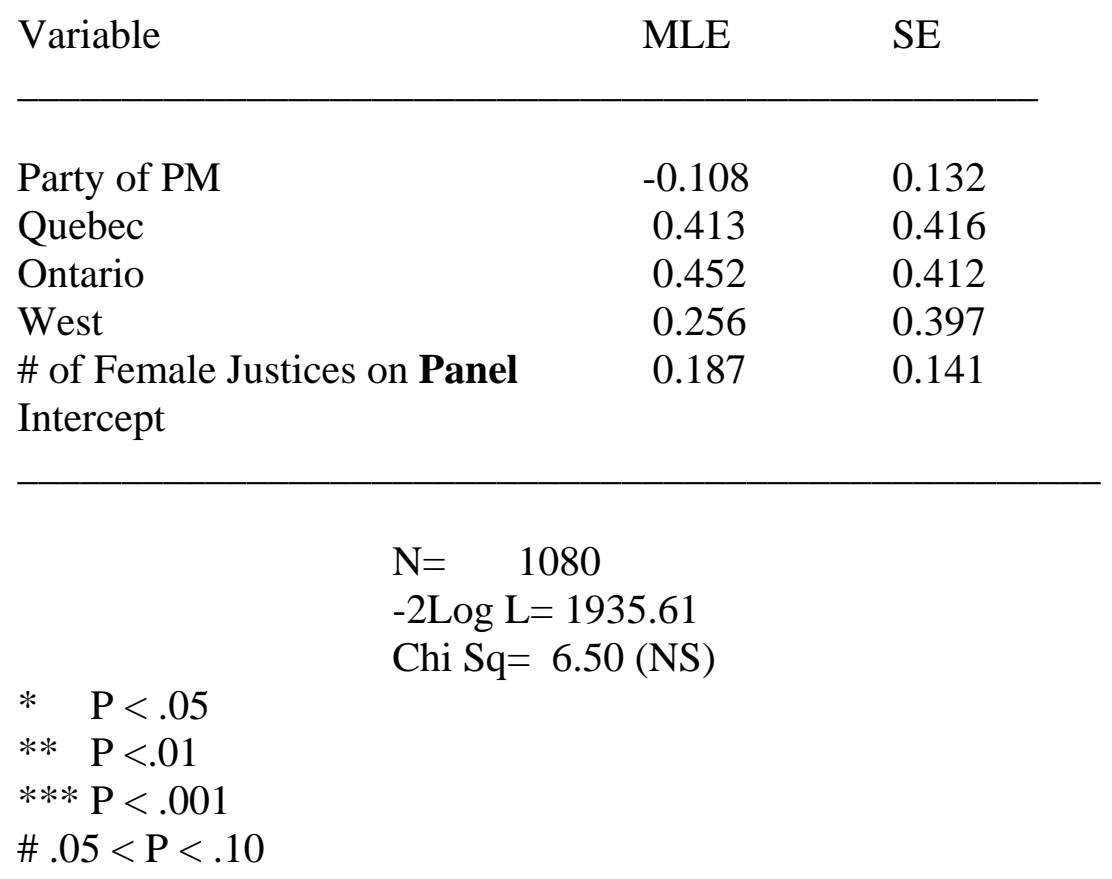

